ISA

Arboriculture \& Urban Forestry 2015. 41(6): 346-354

\title{
Simple Street Tree Sampling
}

\author{
David J. Nowak, Jeffrey T. Walton, James Baldwin, and Jerry Bond
}

\begin{abstract}
Information on street trees is critical for management of this important resource. Sampling of street tree populations provides an efficient means to obtain street tree population information. Long-term repeat measures of street tree samples supply additional information on street tree changes and can be used to report damages from catastrophic events. Analyses of several street tree populations reveal that a $2 \%-3 \%$ sample of block segments with known length within a city will likely produce estimates on the total number of trees with a standard error around $10 \%$ of the total population estimate (relative standard error of $10 \%$ ). Ratio estimates of number trees per length of street sampled reduced the number of block segments needed to attain a $10 \%$ relative standard error. Communities with a small tree population, or analyses of specific subsets of the population (e.g., individual species information), will likely need a higher proportion of block segments sampled to attain the same relative precision. This paper presents a simple means to sample street tree populations to aid in street tree management and presents information on how many block segments need to be sampled to achieve a desired sampling precision. Results can be used to develop simple, cost-efficient, and accurate means to sample street tree populations.

Key Words. Block Sampling; Ratio Estimates; Sample Size; Street Trees.
\end{abstract}

Understanding and quantifying the structure of the street tree resource (e.g., species composition, dbh distribution, health) is critical to basic street tree management. The most appropriate procedure to aid in street tree management is a comprehensive inventory (or census) of the street tree population. These inventories provide data on various tree characteristics and location that are essential to dayto-day management (e.g., Tate 1985; Smiley and Baker 1988). In cases where street tree inventories cannot be conducted (e.g., limited budgets), street tree sampling can provide a relatively inexpensive alternative for acquiring street tree data on overall street tree composition, health, and/or maintenance needs. However, street tree sampling does not provide the essential data (e.g., comprehensive data on specific tree locations and conditions) that inventories can provide. Rather, sampling provides general overall statistics on the street tree population characteristics, such as species composition, tree sizes, health, and/or maintenance needs. Sampling can also provide a useful means to detect changes and essential information needed for budget planning.

One of the goals of sampling is to produce a more precise estimate (e.g., number of trees) at minimal cost. One way to assess precision is to compare the standard error (variability) of the estimate to the estimate itself. Dividing the standard error of an estimate by the estimate value produces a percent relative standard error (RSE). The lower the percent relative standard error, the higher the precision of the estimate. Increasing the sample size often increases precision, but sample design also affects precision.

Various methods of street tree sampling have been reported in the literature. Mohai et al. (1978) and Valentine et al. (1978) describe a method that entails drawing approximately 50 to 100 random samples of streets with a length of two to three city blocks, and systematically sampling every $x$ th tree of a species to produce a sample size of about 100 trees. This method can provide an efficient and accurate estimate of street tree populations, but requires information on species and population distribution such that sampling interval per species can be selected to reach a sample size of 100 trees.

Jaenson et al. (1992) proposed a sampling method that stratifies the cities into zones and randomly samples blocks such that about 2,000 to 2,300 trees are sampled. This method can provide accurate estimates of the street tree popula- 
tion, but requires the extra step of pre-sampling of the zones to determine how to distribute the sample and requires that a certain number of trees be sampled. This methodology was used to estimate street tree population structure and functions in Davis, California, U.S., and Lisbon, Portugal (Maco and McPherson 2003; Soares et al. 2011).

Various studies have investigated simple random samples of street tree populations. Sun and Bassuk (1991) recommended a minimum sample size of between $5 \%$ and $50 \%$ of the population based on computer simulations of hypothetical tree populations. Percent of the population needing to be sampled varied with total population size and species diversity. Alvarez et al. (2005) compared simple random and stratified random sampling (i.e., random sampling within predefined zones) of street trees in a neighborhood of Piracicaba, Brazil. Random sampling of 20 blocks produced a relative standard error (ratio of standard error to total) of $47 \%$. Stratification of the 20 blocks into four zones revealed relative standard errors for the zones that varied between $32 \%$ and $70 \%$. The advantage of simple random sampling lies in its simplicity, but more complex designs can reduce standard errors of the estimate (e.g., Cochran 1977).

The purpose of this paper is to demonstrate a simple random sampling technique of trees within block segments (i.e., road segments between intersections) for assessing street tree populations. In particular, this paper will use street tree data from several cities to: a) determine the sample size (percent of block segments) needed to attain a $10 \%$ relative standard error for the street tree population total and b) illustrate how information on length of block segment can improve the precision of the population estimates. This simple method does not require pre-sampling or preexisting data and will allow for easy and accurate estimates of the street tree population that can be stratified into various zones of the city if desired. All that is required for this sampling is a listing of the individual block segments that make up the study area. If the length of these block segments are also known, then ratio estimates can be used. The ease of this procedure should increase efficiency in collecting street tree population data and improve street tree management.

\section{METHODS}

The approach used in this paper is a simple random sampling of block segments to determine street tree population characteristics. Complete street tree inventory data $(100 \%$ of the street tree population) from six U.S. cities were obtained from the Davey Resource Group: Buffalo, New York (2010 population $=261,310$ people, 105.15 $\mathrm{km}^{2}$, 2,485 people $/ \mathrm{km}^{2}$ ); Lansing, Michigan (114,297 people; $87.80 \mathrm{~km}^{2}, 1,301$ people $\left./ \mathrm{km}^{2}\right)$; Livonia, Michigan (96,942 people; $92.46 \mathrm{~km}^{2}$, 1,048 people $/ \mathrm{km}^{2}$ ); Parkersburg, West Virginia (31,492 people; $29 \mathrm{~km}^{2}, 1,086$ people/ $\left.\mathrm{km}^{2}\right)$; Syracuse, New York (145,170 people; $65 \mathrm{~km}^{2}, 2,233$ people $\left./ \mathrm{km}^{2}\right)$; and Wilmington, Delaware $(70,851$ people; $27.97 \mathrm{~km}^{2}, 2,533$ people $/ \mathrm{km}^{2}$ ). These cities were selected based on available complete street tree inventory data with geographic coordinates so that tree locations could be located on street maps in a geographic information system (GIS) to aid in sample selection and analysis.

Number and length of block segments in each city were determined using TIGER/Line files (U.S. Census Bureau 2013) within a GIS. Block segments were randomly selected, and all trees on the segment (both sides of the road) were assigned to that block segment. Each block segment was then considered a sampling unit or plot. To determine street tree population characteristics and total, plot calculations were done with and without knowing the block segment length. The following text illustrates the calculations. For these examples, suppose the goal of the sampling was to determine the total number of street trees within a city.

\section{Simple Random Sampling (Block Segment Lengths Unknown)}

In a city there are a total of $N$ block segments with the number of trees labeled $y_{i}$ for the $i$-th block segment $(i=1,2, \ldots, N)$. The total number of trees in the population is:

[1] $\quad Y=\sum_{i=1}^{N} y_{i}$

where $\mathrm{Y}$ is the population parameter of interest (the total number of trees).

Now suppose a simple random sample of $n$ block segments is selected without replacement (i.e., the plot is not put back in the sample pool after being 
selected and cannot be selected again). One estimator of the total number of trees $(\hat{T})$ is:

[2] $\hat{T}=N \cdot \bar{y}$

where

[3] $\quad \bar{y}=\frac{1}{n} \sum_{i=1}^{n} y_{i}$

is the mean number of trees per block segment in the sample.

The estimate of the standard error of the total number of trees is calculated as

$$
\widehat{s e}(\widehat{T})=N \cdot \sqrt{\frac{N-n}{N} \cdot \frac{\widehat{\sigma}_{y}^{2}}{n}}
$$

where

$$
\text { [5] } \quad \hat{\sigma}_{y}^{2}=\frac{1}{n-1} \cdot \sum_{i=1}^{n}\left(y_{i}-\bar{y}\right)^{2}
$$

The standard error is a measurement of how well the sample represents the population. The smaller the standard error, the more representative the sample is of the overall population (e.g., Cochran 1977; Thompson 2002).

\section{Simple Random Sampling (Block Segment Lengths Known)}

When the block lengths (where $x_{i}$ is the length $\mathrm{x}$ for the $i$-th block segment) are known, a ratio estimator of trees per road distance can be used to calculate population totals and standard errors. In this case, population total is calculated as

$$
\text { [6] } \hat{T}_{R}=N \cdot \bar{y} \cdot \frac{\bar{X}}{\bar{x}}
$$

where

$$
\text { [7] } \bar{X}=\frac{1}{n} \sum_{i=1}^{N} x_{i}
$$

is the mean of the block segment lengths in the whole population, and

$$
\text { [8] } \bar{x}=\frac{1}{n} \sum_{i=1}^{n} x_{i}
$$

is the mean block segment length in the sample. The subscript $\mathrm{R}$ in $\hat{T}_{R}$ stands for ratio estimator.

As the number of street trees is likely correlated with the length of the block segment (i.e., longer block segments tend to have more trees), the ratio estimator $\hat{T}_{R}$ should be better than the simpler estimator $\hat{T}$. There can be cases when this is not true (Cochran 1977), but these cases are likely rare with street tree populations. If block information can be easily obtained, they would likely be beneficial in reducing the standard error of the estimate.

The estimate of the standard error of $\hat{T}_{R}$ has a similar form to $\hat{T}$ and is given by

$$
\text { [9] } \widehat{\operatorname{se}}\left(\widehat{T}_{R}\right)=N \sqrt{\frac{N-n}{N} \cdot \frac{\widehat{\sigma}_{R}^{2}}{n}}
$$

where

$$
\hat{\sigma}_{R}^{2}=\frac{1}{n-1} \sum_{i=1}^{n}\left(y_{i}-\frac{\bar{y}}{\bar{x}} x_{i}\right)^{2}
$$

Note that the standard error formula for $\hat{T}_{R}$ is an approximation, but is usually very good (Cochran 1977; Schaeffer et al. 1986; Levy and Lemeshow 1991; Thompson 2002). Block length information can be obtained from city GIS shapefiles or from Census Tiger/Line data.

\section{Sample Size}

To help determine the effect of sample size on the standard error for street tree population estimates, various analyses of the six street tree populations were performed. Analyses were performed for the total street tree population and subpopulations (e.g., number of trees in one species) as standard error estimates tend to increase with subpopulation estimates. The goals of the analyses were to determine the number of block segments that need to be sampled to reach a relative standard error of $10 \%$ in each city. The RSE is the ratio of the standard error to the total. For example, a street tree population with 1,000 trees that has a standard error of 300 , which has a RSE of $30 \%$. Analyses were conducted for the total number of street trees, total number of removals, and total number of one species (Norway maple, Acer platanoides) in each city. For each block segment in the city, the number of trees, removals, and Norway maples were calculated, as well as the average and standard deviation of trees per block in each city (Table 1). To show how RSE varies with sample size, the number of block segments 
was varied within the formula for standard error with the known population variance for each city.

\section{Variation in Sample Estimates}

To illustrate how random samples can yield varying estimates of population totals, five block segments in Syracuse, New York, were randomly selected 30 different times to estimate the total street tree population. Then 10 block segments were randomly selected 30 different times, followed by 15 block segments, 20 block segments, and so on, until 100 block segments were randomly selected 30 times. Individual sample estimates along with average street tree population estimates and standard errors from the 30 samples were graphed and contrasted against the actual street tree population total. Plotting the 30 samples gives a visual idea of how much the individual estimates will vary. A larger sample size is not needed as RSE does not need to be estimated and is calculated using the exact formula for RSE for any sample size.

\section{Ratio Estimates}

Street tree data from one city with street length information (Syracuse, New York) were used to illustrate how the RSE may differ between simple random sample estimates and ratio estimates using known block lengths. For each block segment in the city, the number of trees was counted, as well as the average and standard error of trees per block using simple random and ratio estimates based on block length. To illustrate how RSE varies with sample size between the simple random and ratio estimate approaches, the number of block segments sampled was varied within the formula for standard error with the known population variance for each city.

\section{RESULTS}

For five out of the six cities analyzed, the percent of block segments needing to be sampled to attain a $10 \%$ RSE was between $2.2 \%$ and $4.6 \%$, with total number of block segments sampled between 89 and 185 (Table 1; Table 2). However, for the smallest city analyzed, Parkersburg, West Virginia, nearly 32\% of the block segments need to be sampled to attain a $10 \%$ RSE, which required 279 block segments to be sampled. When analyzing subsets of the population (e.g., removals, Norway maples), the number and percent of block segments needing to be sampled to attain a 10\% RSE increased. For removals, the percent of block segments needing to be sampled ranged between $9.7 \%$ and $58.8 \%$; for Norway maple it ranged between $6.0 \%$ and $72.8 \%$ (Table 1 ).

Sample size affected the variability of the estimate. Relative standard error decreased at differing

Table 1. Street tree, removal, and Norway maple statistics for analyzed U.S. cities.

\begin{tabular}{|c|c|c|c|c|c|c|c|c|c|c|c|c|c|c|c|c|}
\hline \multirow[t]{2}{*}{ City } & \multirow{2}{*}{$\begin{array}{l}\text { No. } \\
\text { blocks }\end{array}$} & \multicolumn{5}{|c|}{ Street trees } & \multicolumn{5}{|c|}{ Removals } & \multicolumn{5}{|c|}{ Norway maple } \\
\hline & & Total $^{z}$ & $10 \% \mathrm{RSE}^{\mathrm{y}}$ & $\%^{x}$ & Avg. ${ }^{\mathrm{w}}$ & $\mathrm{SE}^{\mathrm{v}}$ & Total $^{z}$ & $10 \% \mathrm{RSE}^{\mathrm{y}}$ & $\%^{x}$ & Avg.w & $\mathrm{SE}^{\mathrm{v}}$ & Total $^{\mathrm{z}}$ & $10 \% \mathrm{RSE}^{\mathrm{y}}$ & $\%^{x}$ & Avg. ${ }^{w}$ & $\mathrm{SE}^{\mathrm{v}}$ \\
\hline $\begin{array}{l}\text { Buffalo, } \\
\text { New York }\end{array}$ & 5,954 & 67,593 & 145 & 2.4 & 11.4 & 13.8 & 3,119 & 578 & 9.7 & 0.5 & 1.3 & 15,823 & 523 & 8.8 & 2.7 & 6.4 \\
\hline $\begin{array}{l}\text { Lansing, } \\
\text { Michigan }\end{array}$ & 5,381 & 57,902 & 116 & 2.2 & 10.8 & 11.7 & 0 & na & na & 0.0 & 0.0 & 9,788 & 323 & 6.0 & 1.8 & 3.4 \\
\hline $\begin{array}{l}\text { Livonia, } \\
\text { Michigan }\end{array}$ & 3,357 & 37,854 & 89 & 2.7 & 11.3 & 10.7 & 471 & 814 & 24.2 & 0.1 & 0.5 & 10,330 & 277 & 8.3 & 3.1 & 5.3 \\
\hline $\begin{array}{l}\text { Parkersburg, } \\
\text { West Virginia }\end{array}$ & 876 & 1,734 & 279 & 31.8 & 2.0 & 4.0 & 132 & 515 & 58.8 & 0.2 & 0.5 & 107 & 638 & 72.8 & 0.1 & 0.6 \\
\hline $\begin{array}{l}\text { Syracuse, } \\
\text { New York }\end{array}$ & 5,122 & 34,149 & 185 & 3.6 & 6.7 & 9.2 & 2,345 & 654 & 12.8 & 0.5 & 1.3 & 8,357 & 329 & 6.4 & 1.6 & 3.1 \\
\hline $\begin{array}{l}\text { Wilmington, } \\
\text { Delaware }\end{array}$ & 2,132 & 12,586 & 98 & 4.6 & 5.9 & 6.0 & 263 & 770 & 36.1 & 0.1 & 0.4 & 573 & 654 & 30.7 & 0.3 & 0.8 \\
\hline
\end{tabular}


rates among the cities as sample size increased (Figure 1). Testing of various sample sizes in Syracuse, New York (Figure 2), illustrates that as sample size increases, the estimate tends to have reduced variability and cluster more tightly around the population total. With a sample size of five block segments, sample estimates ranged between 2,588 and 81,972 trees; estimates from sampling of 100 block segments ranged between 25,751 and 39,189 trees. The average of 30 selections of all block segment sample sizes ( $\mathrm{n}=5$ to 100$)$ tends to be close to the population total (Figure 2), with the estimates, on average, only being 1,161 trees (3.3\%) from true population total (34,717 trees). The minimum difference was 122 trees $(0.4 \%$; with 80 street segments) and the maximum difference was 2,759 trees (7.9\%; with 15 street segments). However, as sample size increases, the certainty of the population estimate also increases (i.e., one is less likely to get an estimate that is considerably different from the true answer).

Using block lengths for a ratio estimate in Syracuse, New York, reduced the number of plots needed to attain a $10 \%$ RSE compared with simple random sampling by $29 \%$ (from 185 block segments $(3.6 \%$ of block segments) to 131 block segments (2.6\%) (Figure 3). The reduction in relative standard error decreased with each additional plot. The most substantial reduction in RSE occurred in the first 50 plots, with at least a one percent reduction in RSE for the first 17 street segments sampled (Figure 4).

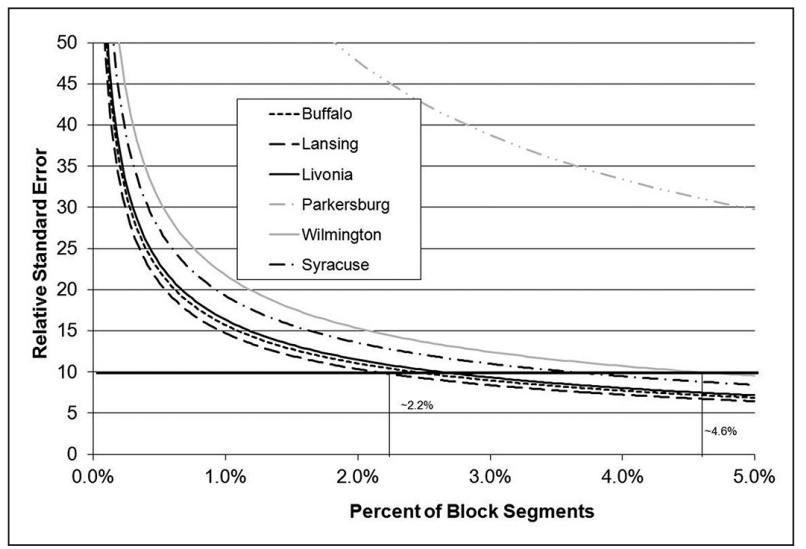

Figure 1. Comparison of relative standard error (RSE) versus percent of block segments sampled in analyzed cities using simple random sampling. For most cities, a 10\% RSE could be reached with a sample between $2.2 \%$ and $4.6 \%$ of the block segments. However, in Parkersburg, West Virginia, a $32 \%$ block sample was needed to attain a $10 \%$ RSE.

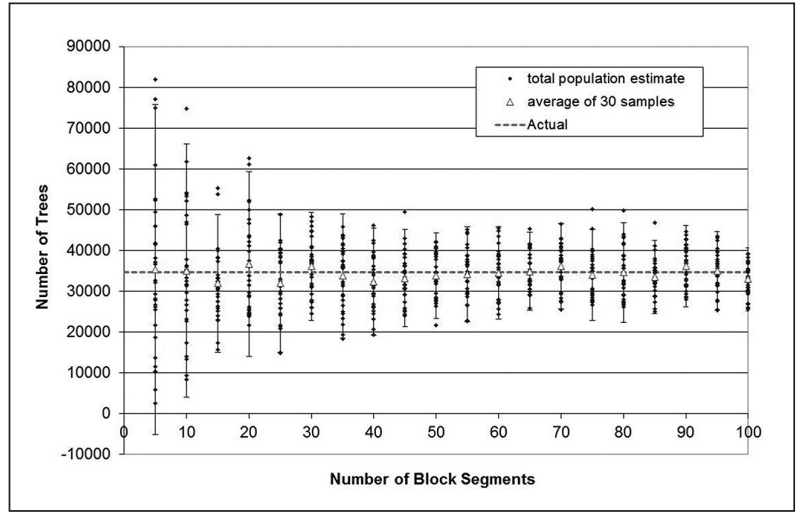

Figure 2. Average and standard error of total street tree population estimate in Syracuse, New York, based on $\mathbf{3 0}$ random samples of varying number of block segments. Dotted line represents the actual street tree total. Dots represent each individual sample estimate. Error bars represent standard error estimate for population total from the 30 samples.

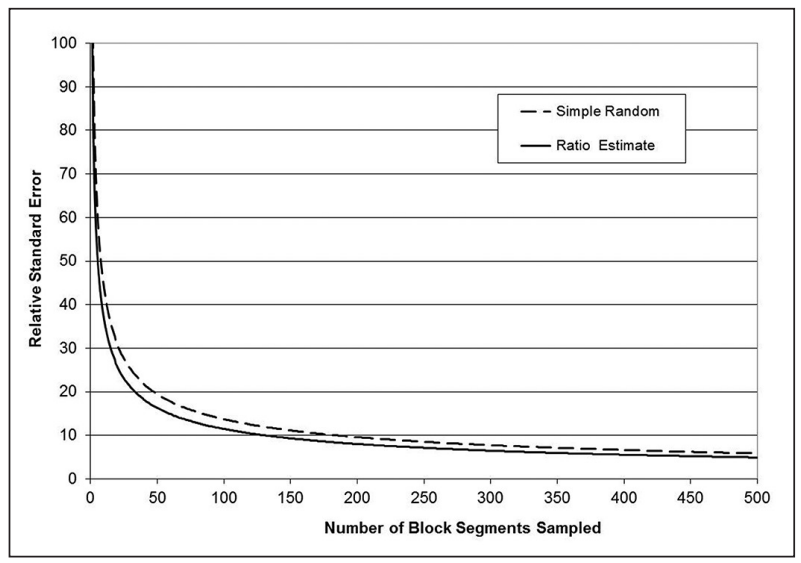

Figure 3. Comparison of relative standard error versus number of sample block segments between simple random sampling and random sampling with known block length (ratio estimate) in Syracuse, New York.

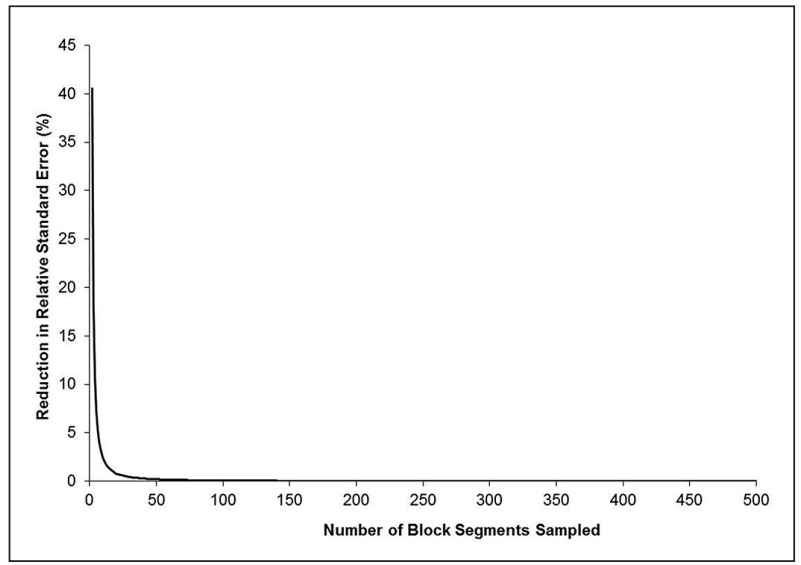

Figure 4. The reduction of relative standard error (from Figure 3) with the addition of one block segment in Syracuse, New York. Reduction in RSE varies depending upon how many block segments were previously sampled (x-axis). 


\section{DISCUSSION}

Street tree sampling is a good option, when 100\% inventories are not feasible, to provide data to aid in street tree management. With the exception of Parkersburg, West Virginia, which had a substantially smaller number of block segments, trees per block segment, and total tree population, a sample size of about $3 \%$ of the block segments (with unknown block length), or between 89 to 185 block segments in a city produced a relative standard error of $10 \%$ (Table 1). Adding block length information to a sample increased precision and reduced the sample size needed to gain desired precision, making sampling more efficient (Figure 3). Increasing the number of block segments sampled also reduced the variability of the estimate (Figure 2).

Urban foresters could begin by sampling $3 \%$ of the block segments to try and attain an estimate of total number of trees with a relative standard error of $10 \%$. If the data are not adequate (e.g., $10 \%$ RSE is not attained), then an additional block segments could be sampling to help reach the desired precision level. However, the decreasing reduction in RSE with additional plots (Figure 4) illustrates that at some point the cost of an increased sample outweighs the gain in precision by taking this additional sample (e.g., Stanovick et al. 2002). Desired sampling precision and costs need to be considered in determining the sampling size.

To increase precision to a $5 \%$ relative standard error for most cities (excluding Parkersburg, West Virginia), an average of $11 \%$, or 462 block segments, were sampled (Table 2). To increase precision to a one-percent relative standard error, an average of about $75 \%$, or 3,240 block segments, were sampled. At this point of precision, it would likely be best to complete a whole street tree inventory with locations and attain 100\% precision. Full inventories can provide more essential data for street tree management than street tree samples.
In cities with small tree populations (e.g., less than 2,000 trees) or for sub-classes within a larger tree population (e.g., individual species), a larger proportion of block segments will be needed to attain a desired relative standard error. However, smaller street tree populations may have a lower absolute standard error than a larger street tree population with a lower RSE. For example, in Lansing, Michigan, a 10\% RSE produces a standard error of 5,790 trees (Table 1). In Parkersburg, West Virginia, a 10\% RSE equates to a standard error of only 173 trees. Thus, Parkersburg could a have a RSE of $100 \%$ (1,734 trees) and still produce an absolute standard error less than Lansing, Michigan. An urban forester must decide what level of precision is desired by the sample and whether the precision is relative to the total (RSE) or an absolute number in terms of trees (standard error).

Simple random sampling or ratio estimates are only one of many possible ways of sampling street tree populations. Although relatively simple, there are other means of sampling that could produce lower relative standard errors. For example, sampling with probability proportional to size, where larger blocks have a higher chance of being selected (compared with equal probabilities of selection as in simple random sampling) could produce lower standard errors, but require additional work in selecting samples (Cochran 1977).

Other enhancements to existing methods (Cochran 1977) could also maximize reductions in standard error for a fixed cost. These techniques consider that getting to a particular randomly selected block is the biggest cost and sampling neighboring blocks can be done at little additional cost. While these approaches can add complexity to the sample design, they can be more cost-effective and produce lower standard errors than simple random sampling. The advantage of simple random sampling lies in its simplicity,

Table 2. Comparison of sample sizes needed to attain various relative standard errors (RSE) for analyzed U.S. cities.

\begin{tabular}{|c|c|c|c|c|c|c|c|c|c|c|c|c|}
\hline \multirow[t]{2}{*}{ RSE } & \multicolumn{2}{|c|}{$\begin{array}{l}\text { Buffalo, } \\
\text { New York }\end{array}$} & \multicolumn{2}{|c|}{$\begin{array}{l}\text { Lansing, } \\
\text { Michigan }\end{array}$} & \multicolumn{2}{|c|}{$\begin{array}{l}\text { Livonia, } \\
\text { Michigan }\end{array}$} & \multicolumn{2}{|c|}{$\begin{array}{l}\text { Parkersburg, } \\
\text { West Virginia }\end{array}$} & \multicolumn{2}{|c|}{$\begin{array}{l}\text { Syracuse, } \\
\text { New York }\end{array}$} & \multicolumn{2}{|c|}{$\begin{array}{l}\text { Wilmington, } \\
\text { Delaware }\end{array}$} \\
\hline & $\%$ & No. & $\%$ & No. & $\%$ & No. & $\%$ & No. & $\%$ & No. & $\%$ & No. \\
\hline $20 \%$ & 0.6 & 37 & 0.6 & 30 & 0.7 & 23 & 10.5 & 92 & 1.2 & 26 & 0.9 & 48 \\
\hline $10 \%$ & 2.4 & 145 & 2.2 & 116 & 2.7 & 89 & 31.8 & 279 & 4.5 & 98 & 3.6 & 185 \\
\hline $5 \%$ & 9.1 & 539 & 8.0 & 433 & 9.7 & 327 & 65.1 & 570 & 16.1 & 343 & 13.0 & 668 \\
\hline $1 \%$ & 71.3 & 4,248 & 68.6 & 3,691 & 73.0 & 2,449 & 98.8 & 858 & 82.7 & 1,764 & 78.9 & 4,043 \\
\hline
\end{tabular}

Note: \% - Percent of total block segments sampled to attain RSE; No. - Number of block segments sampled to attain RSE. 
but more complex designs can potentially reduce costs and standard errors of the estimate.

Stratification of the population in subareas for analysis can reduce standard error if the areas have similar population structure (e.g., similar species and/or sizes). Most stratification for street trees is done based on geography (e.g., management units, neighborhoods). This type of stratification may or may not reduce standard errors, but will provide information on subareas that may be useful management (e.g., neighborhood analyses).

Having block length information adds increased precision to the estimate and is relatively easy to obtain via TIGER/Line files (U.S. Census Bureau 2013). A GIS-based procedure is also available at no cost through the i-Tree software suite (www. itreetools.org) to help randomly select block segments within cities. To aid in the analysis of population or sub-class population totals and standard error, an Excel $^{\odot}$ spreadsheet calculator is available online (Street Tree Calculator 2015), or data can be run through i-Tree.

In establishing a street tree sample, the following types of information should be considered: a) funding-is there funding to establish a complete street tree inventory, and if not, how much is available for sampling; b) variables-what type of information is required from the sample (e.g., number of trees, tree health, maintenance needs, tree sizes, planting sites); c) precision-what is an acceptable standard error for the types of information desired; d) what types of data are available (e.g., any existing street tree data to aid in developing sample design, GIS layer of roads); and e) sample design-will simple random sampling or ratio estimates meet the desired precision, or should other sample designs be developed? Adequate sample preparation and thought can help the sampling process meet the desired objectives of the user in the most cost-effective manner.

If an urban forester would like to sample a street tree population using this procedure, potential step-by-step procedures are as follows:

1. Obtain a list of all block segments and their lengths (e.g., from the city GIS department). If lengths are not available, then obtain a list of all block segments. Block segments should have address information so they can be located in the field.
2. Load the list into a spreadsheet and randomly select $3 \%$ of the block segments

3. Measure all trees on selected block segments (both sides of the street)

4. Summarize data for each block segment in a spreadsheet (e.g., number of trees per block, number of $2.5 \mathrm{~cm}$ Acer rubrum, number of dead trees)

5. Transfer data into i-Tree spreadsheet to calculate totals and standard errors (Street Tree Calculator 2015) or calculate using equations given in methods

6. Optional step: Add additional randomlyselected block segments and measure trees on these block segments if desired precision is not reached in step \#5. Add these new data to existing data in step \#4

7. Re-measure sampled block segments in the future to calculate change

Street tree sampling can also provide a relatively inexpensive means to monitor change in a street tree population. By following a sample tree population through time, information can be attained on rates of changes and factors associated with tree survival or mortality (e.g., what environmental or species factors lead to varying mortality rates). In addition, re-measurement of street tree samples can be used to generate information on tree losses and/or debris clean-up related to storms or other natural events (e.g., pest outbreaks). As street trees are only a small component of the whole urban forest, urban foresters should also consider sampling the whole urban forest (e.g., through i-Tree protocols). This additional sampling would ascertain information on the structure and values associated with entire urban forest resource, as well as potential threats (e.g., pests, climate change) that may alter urban forest structure in the future. 


\section{CONCLUSION}

Although 100\% street tree inventories provide the most useful data for day-to-day street tree management, simple random sampling of a street tree population can provide an easy means to gather information on the street tree resource. For many cities, a $2 \%-3 \%$ sampling of block segments with known block lengths will provide around a $10 \%$ relative standard error for estimates of the total number of trees. Fewer block segments would be needed using ratio estimates. Smaller cities with relatively few trees may require significantly more samples to attain the same relative standard error. For estimates of subpopulation characteristics (e.g., individual species), the relative standard error or estimate uncertainty will increase. The information gained from these sample data can be used to improve urban forest management and budget estimates, as well as provide a means to assess tree damage after catastrophic events and evaluate changes in the street tree population.

Acknowledgments. Thanks to the Davey Resource Group for providing the street tree data used in this study. The use of trade, firm, or corporation names in this publication is for the information and convenience of the reader. Such does not constitute an official endorsement or approval by the United States Department of Agriculture or Forest Service of any product or service to the exclusion of others that may be suitable.

\section{LITERATURE CITED}

Alvarez, I.A., G. Del Nero Velasco, H. Sundfeld Barbin, A.M. Liner Pereira Lima, and H.T. Zarate do Couto. 2005. Comparison of two sampling methods for estimating urban tree density. Journal of Arboriculture 31(5):209-214.

Cochran, W.G. 1977. Sampling Techniques, third edition. John Wiley \& Sons, New York, New York, U.S.

Jaenson, R., N. Bassuk, S. Schwager, and D. Headley. 1992. A statistical method for the accurate and rapid sampling of urban street tree populations. Journal of Arboriculture 18(4):171-183.

Levy, P.S., and S. Lemeshow. 1991. Sampling of Populations: Methods and Applications. John Wiley \& Sons, New York, New York, U.S.

Maco, S.E., and E.G. McPherson. 2003. A practical approach to assessing structure, function, and value of street tree populations in small communities. Journal of Arboriculture 29(2): 84-97.

Mohai, P., L. Smith, F. Valentine, W. Stiteler, T. Elias, and R. Westfall. 1978. Structure of urban street tree populations and sampling designs for estimating their parameters. Metropolitan Tree Improvement Alliance (METRIA) proceedings. 1:28-43.

Schaeffer, R.L., W. Mendenhall, and L. Ott. 1986. Elementary Survey Sampling. Duxbury Press, Boston, Massachusetts, U.S.
Smiley, E.T., and F.A. Baker. 1988. Options in street tree inventories. Journal of Arboriculture 14(2):36-42.

Soares, A.L., F.C. Rego, E.G. McPherson, J.R. Simpson, P.J. Peper, and Q. Xiao. 2011. Benefits and costs of street trees in Lisbon, Portugal. Urban Forestry \& Urban Greening 10:69-78

Stanovick, J.S., R.D. Zweifel, and B. Wagner. 2002. Precision of statistics derived from a statewide angler survey. North American Journal of Fisheries Management 22:1266-1269.

Street Tree Calculator. 2015. Street Tree Sample Population Calculator. <www.itreetools.org/support/Street_Tree_Sample_Population_Calculator.xls $>$

Sun, W.Q., and N.L. Bassuk. 1991. Approach to determine effective sampling size for urban street tree survey. Landscape and Urban Planning 20:277-283.

Tate, R.L. 1985. Uses of street tree inventory data. Journal of Arboriculture 11(7):210-213.

Thompson, S.K. 2002. Sampling, second edition. John Wiley \& Sons, New York, New York, U.S.

U.S. Census Bureau. 2013. TIGER/Line Shapefiles. Last accessed January 2013. <www.census.gov/geo/maps-data/data/tiger.html >

Valentine, F.A., R.D. Westfall, and P.D. Manion. 1978. Street tree assessment by a survey sampling procedure. Journal of Arboriculture 4(3):49-57.

David J. Nowak (corresponding author)

Project Leader

USDA Forest Service, Northern Research Station

5 Moon Library, SUNY-ESF

Syracuse, New York 13210, U.S.

dnowak@fs.fed.us

Jeffrey T. Walton

Professor

Paul Smith's College

Routes 86 \& 30

P.O. Box 265

Paul Smiths, New York 12970-0265, U.S.

jwalton@paulsmiths.edu

James Baldwin

Statistician

USDA Forest Service, Pacific Southwest Research Station

800 Buchanan St. West Annex Building

Albany, California 94710-0011, U.S.

JBaldwin@fs.fed.us

Jerry Bond

Consulting Urban Forester

Urban Forest Analytics LLC

3904 Willowdale Lane

Geneva, New York 14456-9267, U.S.

jerry@urbanforestanalytics.com 
Résumé. Les données sur les arbres d'alignement sont essentielles pour la gestion de cette importante ressource. Léchantillonnage des populations d'arbres d'alignement constitue un moyen efficace d'obtenir de l'information à leur sujet. La cueillette répétée de données sur les arbres d'alignement pendant une longue période fournit des informations additionnelles sur les transformations que subissent ces arbres et peuvent être utilisées pour constater des dommages à la suite d'événements catastrophiques. Les analyses de plusieurs populations d'arbres d'alignement révèlent qu'un échantillonnage de $2 \%$ à $3 \%$ des tronçons de rue d'une longueur donnée d'une ville permettrait vraisemblablement de produire des estimations sur le nombre total d'arbres avec une marge d'erreur type d'environ $10 \%$ de la population totale estimée (erreur type relative de 10\%). Des estimations du ratio du nombre d'arbres par tronçons échantillonnés réduiront le nombre de tronçons nécessaires afin d'atteindre un écart type relatif de $10 \%$. Les communautés ayant de plus petites populations d'arbres ou les analyses de sous-ensembles spécifiques de la population (les données sur chaque espèce, par exemple), nécessiteront selon toute vraisemblance un plus grand échantillonnage de tronçons afin d'atteindre le même niveau de précision relative. Cet article présente une méthode simple pour échantillonner les populations d'arbres d'alignement afin d'améliorer leur gestion et fournit de l'information sur le nombre de tronçons devant être échantillonnés afin d'atteindre la précision d'échantillonnage souhaitée. Les résultats peuvent être utilisés afin de développer des méthodes simples, rentables et précises pour l'échantillonnage des populations d'arbres d'alignement.

Zusammenfassung. Für das Management dieser Ressource sind Informationen über Straßenbäume entscheidend. Eine Probennahme von Straßenbaumpopulationen liefert effiziente Werte, um Informationen über Straßenbäume zu erhalten. Langzeitliche, wiederholte Messungen von Straßenbaumproben liefern zusätzliche Informationen über die Veränderungen von Straßenbäumen und können dazu verwendet werden, die Schäden aus Naturkatastrophen aufzunehmen. Analysen von verschiedenen Straßenbaumpopulationen enthüllten, dass eine 2\%-3\%ige Probe aus Blocksegmenten mit bekannter Länge innerhalb einer Stadt wahrscheinlich Schätzungen der totalen Baumanzahl mit einem Standardfehler um 10\% der Gesamtpopulationsschätzung (relativer Standardfehler um 10\%) produziert. Schätzungen des Verhältnisses von Anzahl der Bäume pro beprobter Straßenlänge reduzierte die Anzahl der Blockelemente, die erforderlich sind, um eine 10\%ige Standardabweichung zu erzielen. Kommunen mit kleinen Baumpopulationen oder Analysen spezifischen Teilbereichen der Population (z.B. individuelle Spezies-Information) werden wahrscheinlich eine höhere Anzahl von Blocksegmenten beproben müssen, um die vergleichbare Präzision zu erzielen. Diese Studie präsentiert ein einfaches Mittel, Straßenbaumpopulation zu beproben, um einen Beitrag zum Straßenbaummanagement und liefert Informationen darüber, wie viele Blocksegmente beprobt werden müssen, um eine erwünschte Präzision zu erzielen. Die Ergebnisse können zur Entwicklung einfacher, kosten-effizienter und akkurater Mittel zum Testen von Straßenbaumpopulationen verwendet werden.

Resumen. La información sobre los árboles urbanos es fundamental para la gestión de este importante recurso. El muestreo de las poblaciones de árboles proporciona un medio eficaz para obtener información sobre la población de árboles urbanos. Mediciones repetidas a largo plazo de las muestras de los árboles proporcionan información adicional sobre los cambios en el árbol y se pueden utilizar para reportar daños por eventos catastróficos. Los análisis de varias poblaciones de árboles revelan que un 2\% -3\% de la muestra de segmentos de manzanas con longitud conocida dentro de una ciudad es probable que produzcan estimaciones sobre el número total de árboles con un error estándar de alrededor del 10\% de la población total estimada (error estándar relativo de 10\%). Estimaciones del número de árboles por longitud de calle muestreada redujeron el número de segmentos de manzanas necesarias para alcanzar un error estándar relativa del $10 \%$. Las comunidades con una pequeña población de árboles, o los análisis de subgrupos específicos de la población (por ejemplo, información sobre especies individuales), es probable que necesite una mayor proporción de segmentos de manzanas incluidos en la muestra para alcanzar la misma precisión relativa. Este trabajo presenta un medio sencillo para muestrear poblaciones de árboles urbanos para ayudar en la gestión de los árboles y presenta información sobre cómo deben ser muestreados para lograr una precisión de muestreo deseada. Los resultados pueden ser utilizados para desarrollar métodos simples, rentables y precisos para muestrear las poblaciones de árboles urbanos. 